\title{
Islam dan Keindonesiaan \\ Himpunan Mahasiswa Islam dalam Dinamika Keumatan Kebangsaan
}

\author{
Abdul Karim* \\ Ismail Suardi Wekke** \\ Natsar Desi**** \\ *Sekolah Tinggi Ilmu Ekonomi (STIE) Amkop Makassar \\ **Institut Agama Islam Negeri (IAIN) Sorong \\ The Jusuf Kalla Research Center for Bugis Makassar Cultural Studies \\ Universitas Muslim Indonesia \\ ***Universitas Fajar, Makassar

\section{Undangan Menulis}

\section{Pendahuluan}

Prakarsa ini lahir dari obrolan warung kopi. Dimana pilihan serba terbatas dalam suasana pandemi. Walaupun demikian, tetap saja ada hal-hal yang dapat diteruskan. Baik semasa pandemi, maupun setelahnya nanti. Diantara keterbatasan itu, justru memiliki kesempatan untuk mengetikkan kembali pelbagai minat diantaranya masa-masa Milad HmI.

Suasana ngopi malam itu, dimana memilih tempat untuk duduk di warung kopi yang dikelola kader HmI. Sekaligus pada saat yang sama, ikhtiar untuk menapaki kemampuan ekonomi. Sehingga tidak lagi hanya sekadar diskursus atau "sekadar wacana" yang jamak disampaikan dalam pelbagai percakapan HmI. Namun, justru warung kopi itu menjadi monument untuk melangkah dalam bentuk usaha. Bukan lagi sekadar wacana.

Meneruskan obrolan itu, kemudian judul ini menjadi pilihan Islam dan Keindonesiaan. Sekaligus tetap meneruskan syarahan NDP. Dimana perlu deskripsi topik-topik Esensi Ajaran Islam, dan juga Problematika Umat Islam. Menapaki jenjang formal perkaderan seperti Latihan Kader (LK) III, maka tidak lagi sekadar memotretnya dalam skala nasional. Tetapi juga sampai pada skala global.

Dalam konteks ini, maka perlu kembali mengecek penggunaan kata-kata Intermediate Nasional, Intermediate Internasional, dalam pelaksanaan LK. Sejatinya, kata-kata tersebut justru menjadi dekorasi semata. Komitmen keislaman HmI, sejak awal walaupun dalam konteks Indonesia tetapi juga sudah mengglobal. Termasuk adaptasi kecenderungan keilmuan dunia Islam ketika penyusunan Nilai Dasar Perjuangan (NDP). Sehingga dalam perkembangannya, HmI tidak memilih menggunakan Indonesia sebagai nama, pondasi komitmen ke-HmI-an justru sudah diletakkan sejak sebelum pendirian.

Buku ini merupakan cara pandang internal HmI. Selama ini, pandangan-pandangan eksternal menjadi pelengkap dalam memotret perjalanan 74 tahun HmI.

\section{Panduan Penulisan}

Untuk penulisan bab dalam buku, direkomendasikan menuliskan factual/fenomena. Tidak lagi hanya romantisme Yogyakarta, masa-masa sulit HMI di mata PKI, pembaruan pemikiran Islam Cak Nur. Tema-tema yang memungkinkan adalah sejarah local, perjumpaan HmI dengan kearifan lokal. Termasuk kemungkinan adanya gelombang kedua pemikiran Islam (Sabri, Wekke, \& Ikhsan, 2017).

Begitu pula interdisipliner perspektif, memungkinkan kajian-kajian HmI dalam topik Islam dan Keindonesiaan yang luas. Tidak ditulis dalam sekadar literatur review, tetapi juga pada kondisi faktual. Jika menyimak artikel seiring dengan 74 tahun HmI, rujukannya pada momentum Romantisme Yogyakarta, PKI, ataupun Cak Nur. Padahal, dalam terma-terma di HmI ada pelbagai topik yang memungkinkan untuk diteroka. 
Fase HmI telah bergerak ke masa kini. Tidak hanya tentang PKI (Drakeley, 2014). Juga terkait Cak Nur (Wekke, 2020), ataupun asas tunggal yang hingga kini membelah HmI menjadi HmI DIPO yang sekretariatnya dulu di Jl. Diponegoro, dan HmI MPO (Saleh, 1996).

Salah satu tuntutan hari ini, dimana isu-isu lingkungan juga menjadi gerakan arus utama mahasiswa. Bahkan, mengintegrasikan lingkungan menjadi gerakan HmI. Dimana pendidikan dan pembelajaran memerlukan adanya pengarusutamaan lingkungan (Desi, Alam, Rifdan, \& Pertiwi, 2017). Dalam lapangan kehidupan yang luas, justru peran-peran kemasyarakatan HmI dapat ditegakkan (Maddatuang, Sabara, Wekke, \& Karim, 2020).

\section{Teknis Penulisan} berikut:

Undangan menulis untuk bab dalam buku ditulis dengan panduan dengan uraian sebagai

1. Ditulis dengan tidak hanya opini semata, tetapi juga ada data dan pembahasan. Tema diarahkan pada kondisi kekinian. Penulis perlu memperhatikan State of the Art.

2. Referensi yang digunakan, sumber-sumber utama, primer, mutakhir, dan relevan. Tidak perlu menggunakan acuan pada blog atau media sosial kepenulisan.

3. Menggunakan gaya penulisan APA, dengan format nama terakhir penulis tahun (fulan, 2021). Tidak perlu mencantumkan halaman.

4. Panjang tulisan 3.500-5.000 kata.

5. Disertakan profil singkat 200-250 kata.

6. Dikirim ke: Islahuddin Ibrahim <islahuddiniccha08 at gmail dot com>.

7. Batas penerimaan 1 April 2021, puku 23:59 WITA.

\section{Bibliografi}

Desi, N., Alam, M., Rifdan, L., \& Pertiwi, N. (2017). Environmental Education Training Model to Improve Knowledge and Attitudes on the Friendly Environment of Community Organizations Members in Makassar. Research Journal of Applied Sciences, 12(2), 125-130.

Drakeley, S. (2014). Indonesia's Muslim Organisations and the Overthrow of Sukarno. Studia Islamika, 21(2), 197-231.

Maddatuang, B., Sabara, Z., Wekke, I. S., \& Karim, A. (2020). Langkah Mewujudkan Insan Cita Pandangan Lintas Disiplin. Sidoarjo: Penerbit Qiara Media.

Sabri, M., Wekke, I. S., \& Ikhsan, M. (2017). Islam, Keindonesiaan dan Postmodernitas. Malang: Inteligensia Media.

Saleh, H. M. (1996). HMI dan rekayasa asas tunggal Pancasila. Kelompok Studi Lingkaran.

Wekke, I. S. (2020). Nurcholish Madjid, Mozaik Himpunan Mahasiswa Islam. https://doi.org/10.31219/osf.io/x9q24. 